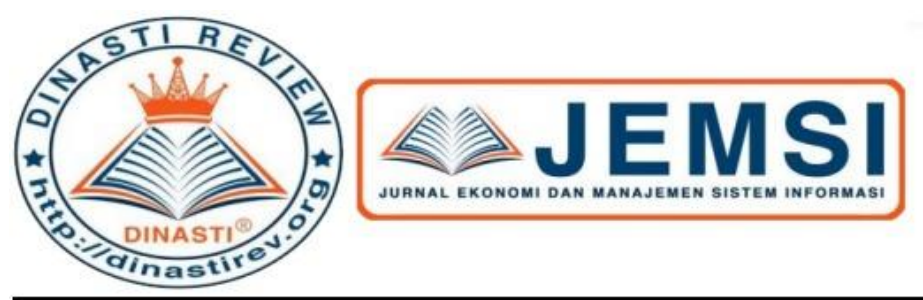

$+62878-9658-6407$

087896586407 ()

https://dinastirev.org/JEMSI (8)

editor@dinastirev.org (G.

\title{
EFEKTIVITAS PENGEMBANGAN SUMBER DAYA MANUSIA APARATUR MELALUI DIKLAT MANAGEMENT OF TRAINING (MOT) BPSDM PROVINSI
} JAMBI

\author{
Sultoni ${ }^{1)}$ \\ 1) Badan Pengembangan Sumber Daya Manusia, Jambi, Indonesia
}

\begin{tabular}{|c|l|}
\hline ARTICLE INFORMATION & $\begin{array}{l}\text { Abstrak: Sumber daya manusia sebagai pemilik, pengolah, } \\
\text { pengelola, dan pengguna pengetahuan memerlukan sarana yang } \\
\text { Revised: 8 Januari 2020 } \\
\text { menunjang tercapainya informasi yang mendukung dan } \\
\text { Issued: 11 Januari 2020 } \\
\text { menambah pengetahuannya. Oleh karena itu diperlukan } \\
\text { pengembangan sumber daya manusia dalam organisasi untuk } \\
\text { meningkatkan kompetensi sumber daya manusia, Badan } \\
\text { pengembangan sumber daya manusia (BPSDM) Provinsi Jambi } \\
\text { adalah merupakan suatu lembaga terakreditasi di daerah } \\
\text { Provinsi Jambi, yang melaksanakan pelaksanaan pendidikan } \\
\text { pelatihan perlu melakukan terobosan-terobosan untuk } \\
\text { pengembangan sumber daya manusia. Kinerja diklat } \\
\text { menunjukkan tingkat capaian kinerja dari suatu program diklat } \\
\text { atau lembaga diklat. Kinerja diklat - baik kinerja dari program } \\
\text { diklat ataupun kinerja lembaga diklat - memiliki keterkaitan } \\
\text { yang sangat erat dengan keberadaan suatu lembaga diklat. } \\
\text { Kata Kunci: Efektifitas pengembangan, Diklat, Management } \\
\text { of Training }\end{array}$ \\
\hline
\end{tabular}

\section{PENDAHULUAN}

Manajemen merupakan suatu alat untuk mencapai tujuan yang diinginkan. Salah satu unsur manajemen adalah Manajemen Sumber Daya Manusia. Sumber daya manusia merupakan aset yang paling penting bagi organisasi diantara sumber daya lainnya. Dari berbagai sumber daya yang dimiliki organisasi perangkat daerah, SDM menempati posisi strategis. Tanpa sumber daya manusia, sumber daya yang lain tidak bisa dimanfaatkan, apalagi dikelola untuk menghasilkan suatu produk karena sumber daya manusia yang menggerakkan dan membuat sumber daya lainnya bekerja.

Badan pengembangan sumber daya manusia (BPSDM) Provinsi Jambi adalah merupakan suatu lembaga terakreditasi di daerah Provinsi Jambi, yang melaksanakan pelaksanaan pendidikan pelatihan perlu melakukan terobosan-terobosan untuk pengembangan sumber daya manusia dalam rangka melaksanakan peraturan pemerintah No. 11 Tahun 2017 tentang manajemen ASN. Di tegaskan bahwa setiap pegawai negeri sipil berhak memperoleh pelatihan klasikal/non klasikal (sebanyak $20 \mathrm{JP}$ )/tahun. Hal ini lah yang menjadi pemikiran bagi penulis untuk dapat menuangkan kedalam rencana penulisan karya tulis ilmiah supaya dapat bersinergi antara pemerintah provinsi dan pemerintah kabupaten/kota.

Dalam kenyataannya masih banyak organisasi perangkat daerah tidak menyadari pentingnya sumber daya manusia bagi kelangsungan hidup oganisasinya SDM (sumber daya manusia) masih dianggap sebagai salah satu faktor produksi dan bukan sebagai aset organisasi perangkat daerah. Tetapi pada dasarnya untuk menghadapi perkembangan teknologi yang cepat, sumber daya manusia yang akan menjadi kekuatan bagi organisasi perangkat daerah 
untuk bertahan hidup dan kekuatan untuk menghadapi persaingan. Perkembangan teknologi yang cepat menuntut kemampuan mereka dalam menangkap berbagai fenomena perubahan tersebut, menganalisa kompetensi dampaknya terhadap organisasi dan menyiapkan langkahlangkah guna menghadapi kondisi tersebut.

Perubahan yang terjadi dalam era global dewasa ini, memiliki ciri khusus antara lain sulit diduga, mengejutkan bersifat kompleks dan memicu timbulnya konflik dalam organisasi. Kita akan selalu di hadapkan dengan tantangan-tantangan yang tidak pernah terjadi sebelumnya. Situasi persaingan yang semakin ketat dari waktu ke waktu menuntut organisasi untuk selalu meningkatkan kualitas sumber daya manusianya agar dapat bertahan. Salah satu upaya strategis yang dapat dilakukan dalam peningkatan kualitas sumber daya manusia ini adalah melalui Diklat.

Sumber daya manusia sebagai pemilik, pengolah, pengelola, dan pengguna pengetahuan memerlukan sarana yang menunjang tercapainya informasi yang mendukung dan menambah pengetahuannya. Oleh karena itu diperlukan pengembangan sumber daya manusia dalam organisasi untuk meningkatkan kompetensi sumber daya manusia. Manajemen dapat memfasilitasi pengembangan sumber daya manusia untuk mendukung keberhasilan pengembangan tersebut. Manajemen sumber daya manusia mendorong setiap aparatur untuk melaksanakan strategi yang telah diterapkan oleh organisasi perangkat daerah. Hal itu dapat dilakukan dengan meningkatkan keterampilan dan pengetahuan tenaga aparatur yang diwujudkan dalam berbagai bentuk nyata, misalnya pemberian pendidikan dan pelatihan, mengadakan seminar-seminar, pemberian kursus keterampilan, dan kegiatan-kegiatan lain.

Dalam kenyataannya masih banyak organisasi perangkat daerah tidak menyadari pentingnya sumber daya manusia bagi kelangsungan hidup oganisasinya SDM (sumber daya manusia) masih dianggap sebagai salah satu faktor produksi dan bukan sebagai aset organisasi perangkat daerah. Tetapi pada dasarnya untuk menghadapi perkembangan teknologi yang cepat, sumber daya manusia yang akan menjadi kekuatan bagi organisasi perangkat daerah untuk bertahan hidup dan kekuatan untuk menghadapi persaingan. Perkembangan teknologi yang cepat menuntut kemampuan mereka dalam menangkap berbagai fenomena perubahan tersebut, menganalisa kompetensi dampaknya terhadap organisasi dan menyiapkan langkahlangkah guna menghadapi kondisi tersebut.

Sumber daya manusia sebagai pemilik, pengolah, pengelola, dan pengguna pengetahuan memerlukan sarana yang menunjang tercapainya informasi yang mendukung dan menambah pengetahuannya. Oleh karena itu diperlukan pengembangan sumber daya manusia dalam organisasi untuk meningkatkan kompetensi sumber daya manusia. Manajemen dapat memfasilitasi pengembangan sumber daya manusia untuk mendukung keberhasilan pengembangan tersebut. Manajemen sumber daya manusia mendorong setiap aparatur untuk melaksanakan strategi yang telah diterapkan oleh organisasi perangkat daerah. Hal itu dapat dilakukan dengan meningkatkan keterampilan dan pengetahuan tenaga aparatur yang diwujudkan dalam berbagai bentuk nyata, misalnya pemberian pendidikan dan pelatihan, mengadakan seminar-seminar, pemberian kursus keterampilan, dan kegiatan-kegiatan lain.

Pada kondisi saat ini, Badan Pengembangan Sumber Daya Manusia Provinsi Jambi belum memiliki data dan informasi yang akurat mengenai program pengembangan sumber daya manusia melalui diklat MOT.

Sesuai dengan tugas dan fungsi sebagai unsur pendukung Gubernur Jambi di dalam penyelenggaraan tugas pemerintahan dan pembangunan khususnya di bidang kompetensi pegawai/aparatur, Badan Pengembangan Sumber Daya Manusia Provinsi Jambi berupaya dan berkomitmen kuat untuk melaksanakan pembinaan dan pengembangan kompetensi sumber daya aparatur yang menekankan hak dan kewajiban individual pegawai menuju perspektif baru manajemen pengembangan sumber daya manusia secara strategis (strategic human resource management) agar selalu tersedia sumber daya aparatur sipil unggulan yang selaras dengan 
dinamika perubahan misi aparatur sipil negara maupun visi dan misi Gubernur yang tersurat dalam Rencana Pembangunan Jangka Menengah Daerah (RPJMD) Provinsi Jambi.

\section{Identifikasi Masalah}

Dalam melaksanakan tugas dan fungsi Badan Pengembangan Sumber Daya Manusia Provinsi Jambi menghadapi berbagai identifikasi masalah yang secara rinci dapat diuraikan pada aspek-aspek berikut:

1. Belum optimalnya Program pengembangan Sumber Daya Manusia aparatur dalam melaksanakan pendidikan dan pelatihan.

2. Masih rendahnya Sumber Daya Manusia yang dimiliki Badan Pengembangan Sumber Daya Manusia Provinsi Jambi yang terkait dengan kompetensi pengelelola diklat yang profesional.

Masih rendahnya kolaborasi dengan jejaring kerja dalam melaksanakan pendidikan dan pelatihan sesuai dengan diklat MOT.

\section{KAJIAN PUSTAKA \\ Kinerja}

Pengertian kinerja sebenarnya tidak hanya sekedar output yang dihasilkan oleh seorang PNS dalam menyelesaikan suatu kegiatan. Kinerja memiliki makna yang lebih luas dari sebatas output yang dihasilkan. Output hanya salah satu bagian yang membentuk kinerja. Berdasarkan pemikiran yang dikembangkan para ahli, kinerja juga memberikan perhatian pada input, proses dan dampak dari suatu kegiatan yang dilakukan. Kinerja yang baik adalah hasil yang terbentuk dari sekumpulan input dan proses yang baik sehingga menghasilkan output dan dampak yang optimal bagi organisasi atau stakeholders- nya.

Secara sederhana kinerja dapat diartikan sebagai suatu kegiatan atau pekerjaan yang berhasil mencapai tujuan dan memberikan dampak atau manfaat terhadap sesuatu. Sesuatu disini dapat berupa organisasi, masyarakat, pelayanan umum, perekonomian, parawisata dan lain-lain. Jika suatu pekerjaan menghasilkan output tetapi tidak memberikan dampak atau manfaat sebagaimana yang diharapkan selayaknya pekerjaan tadi dianggap belum menghasilkan kinerja yang optimal. Boleh jadi seorang pegawai negeri sipil sangat disiplin atau rajin bekerja. Akan tetapi, jika kerajinan yang diperlihatkan atau hasil pekerjaannya tidak memberikan dampak bsgi pencapaian tujuan instansinya, dapat di katakan bahwa kinerja nya belum optimal. Kinerja memberikan perhatian pada input, proses, output dan dampak/manfaat tetapi lebih menekankan pada dampak/manfaat yang dicapai.

\section{Kinerja Diklat}

Pengertian tentang kinerja diklat secara khusus sebenarnya belum banyak dibahas oleh para ahli. Yang banyak ditemui dalam buku-buku teks adalah kinerja sumber daya manusia atau kinerja organisasi mulai dari perencanaannya sampai pada pemilaiannya. Berangkat dari pengertian kinerja sebagaimana diuraikan diatas, dapat dijelaskan bahwa kinerja diklat berarti kinerja yang berhubungan dengan penyelenggaraan suatu program diklat atau kinerja yang berhubungan dengan suatu lembaga diklat. Kinerja diklat menunjukkan tingkat capaian kinerja dari suatu program diklat atau lembaga diklat. Dalam praktiknya, tidak semua program diklat atau lembaga diklat yang berhasil mencapai tingkat kinerja tertentu. Suatu program diklat, walaupun telah dilaksanakan sesuai rencana belum tentu mencapai kinerja. Dengan demikian, kinerja diklat tidak semata-mata dilihat dari keberhasilan teknis penyelenggaraan nya, seperti kebutuhan sarana dan prasarana saja. 


\section{Pentingnya Kinerja DIklat}

Kinerja diklat - baik kinerja dari program diklat maupun kinerja lembaga diklat memiliki keterkaitan yang sangat erat dengan keberadaan suatu lembaga diklat. Tujuan dari suatu lembaga diklat akan tercapai jika program - program diklat yang diselenggarakan mampu mencapai tingkat kinerja sebagaimana yang diharapkan. Dan, program diklat dapat mencapai target/sasaran kinerja tertentu jika setiap individu dalam lembaga diklat tersebut juga memiliki kinerja. Dengan demikian, terdapat hubungan yang sangat jelas antara kinerja individu penyelenggaraan diklat dengan kinerja program diklat dan juga kinerja lembaga diklat.

Dalam konteks pengembangan sumber daya manusia aparatur secara keseluruhan, jika ingin meningkatkan kapasitas SDM aparatur tersebut maka perlu diperhatikan sudah sejauh mana program -program diklat yang di selenggarakan di lingkungan pemerintah pusat ataupun pmerintah daerah mencapai target/ sasaran kinerjanya. Dengan kata lain, dalam system diklat PNS, pngembangan kompetensi PNS harus dikawal dari pencapaian indicator keberhasilan.

\section{Manfaat Kinerja}

Pengertian manajemen kinerja banyak dikemukakan oleh para ahli. Sebagian pengertian atau definisi tersebut sengaja dikutip di sini untuk memberikan gambaran mengenai apa yang dimaksud dengan manajemen kinerja. Armstrong and Baron (1998:7) mendefinisikan manajemen kinerja sebagai:

"a strategic and integrated approach to delivering sustained success to organization by improving the performance of the people who work in team and by developing the capabilities of teams and individual contributors"

Pengertian ini menegaskan bahwa sebagai sebuah pendekatan yang strategis dan terintegrasi, manajemen kinerja ditujukan untuk mencapai keberhasilan organisasi secara berkelanjutan dengan memperbaiki kinerja dan mengembangkan kemampuan orang-orang yang bekerja dalam organisasi tersebut. Secara eksplisit Armstrong dan Baron menekankan bahwa kinerja individual memegang peranan yang sangat krusial dalam mencapai keberhasilan organisasi. Setiap individu perlu dikembangkan kemampuannya agar mampu menjalankan tugas dan peranannya secara optimal. Individu yang memiliki kinerja dan memiliki kemampuan selanjutnya diharapkan dapat memberikan kontribusi terbesar bagi keberhasilan pencapaian tujuan organisasi. Oleh karena itu, dapat dikatakan bahwa kberhasilan organisasi ditopang oleh kinerja setiap individuyang terdapat dalam organisasi tersebut. Seandainya ada pegawai dalam suatu organisasi yang tidak memberikan kontribusi apapun terhadap pencapaian tujuan organisasi, maka kondisi ini perlu mendapat perhatian serius dari organisasi atau atasannya.

\section{Siklus Manajemen Kerja}

Manajemen kinerja memiliki siklus yang pada dasarnya tidak jauh berbeda dengan siklus manajemen pada umumnya, yaitu adanya perencanaan (planning), pengelolaan (organizing), pelaksanaan (actuating), dan pengawasan (controlling). Armstrong (2006:16) menggambarkan manajemen kinerja ini sebagai sebuah siklus yang memperbarui dirinya sendiri secara terus menerus (continuous self-renewing cycle). 


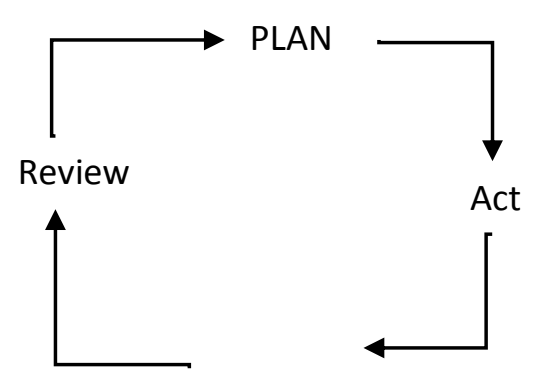

\section{Gambar 1. Siklus Manajemen Kinerja}

\section{Pengertian Perencanaan Kinerja Diklat}

Siklus atau prinsip manajemen yang lazim dikenal umumnya terdiri dari pernecanaan (planning), pengelolaan (organizing), implementasi (actuating) dan pengawasan (controlling). Biasa disingkat POAC. Ini merupakan siklus yang biasa dilakukan dalam pengelolaan suatu pekerjaan atau aktivitas baik dilingkungan organisasi public maupun di organisasi swasta.

Manajemen kinerja adalah bagian dari manajemen pada umumnya yang kita kenal selama ini. Bedanya, manajemen kinerja ditujukan secara spesifik untuk pengelolaan kinerja baik untuk personal ataupun organisasi. Manajemen kinerja untuk program diklat dan lembaga diklat bertujuan untuk meningkatkan kinerja penyelenggaraan program diklat di lembaga lembaga diklat melalui tahapan - tahapan pelaksanaan manajemen kinerja. Pengelolaan program-program diklat pada prinsipnya mengikuti siklus manajemen kinerja seperti telah dibahas sebelumnya. Manajemen kinerja diklat diawali dengan perencanaan kinerja diklat atau performance planning for training and development. Perencanaan kinerja diklat adalah tahap awal dari keseluruhan proses implementasi manajemen kinerja dan merupakan tahap yang sangat menentukan bagi keberhasilan penerapan manajemen kinerja di lembaga-lembaga diklat. Kegagalan dalam melakukan perencanaan kinerja akan membawa konsekuensi bagi tahapan-tahapan selanjutnya. Tanpa perencanaan kinerja yang baik, dapat dipastikan bahwa manajemen kinerja tidak akan menghasilkan kinerja sebagaimana yang diharapkan.

Salah satu factor yang menyebabkan kurang efektifnya upaya peningkatan kinerja program/lembaga diklat selama ini adalah tidak adanya perencanaan kinerja diklat. Perencanaan kinerja diklat tidak pernah atau jarang dibuat sehingga kita tidak tahu kemana perbaikan kinerja diklat itu akan diarahkan dan seperti apa kinerja yang diharapkan tersebut.

\section{Fungsi Perencanaan Kinerja Diklat}

Perencanaan kinerja diklat mmiliki banyak fungsi dalam rangka mengawal proses pencapaian kinerja program diklat. Perencanaan kinerja diklat ini merupakan fondasi bagi pelaksanaan manajemen kinerja di suatu organisasi. Terdapat 6 (enam) fungsi perencanaan kinerja diklat, yaitu:

1. Perencanaan kinerja diklat adalah kerangka dasar bagi implementasi manajemen kinerja bagi program diklat dan lembaga-lembaga diklat. Dengan adanya perencanaan kinerja diklat, kepala lembaga diklat ataupun stakeholder dapat mengetahui apa yang dilakukan selama penyelenggaraan suatu program diklat dan apa yang harus dicapai.

2. Perencanaan kinerja diklat juga memberikan dasar bagi pengelolaan kinerja diklat sepanjang penyelenggaraan diklat tersebut. Dengan berpegang pada perencanaan kinerja diklat, kepala lembaga diklat ataupun stakeholder dapat mengetahui apakah diklat yang diselenggarakan berhasil mencapai target/sasaran kinerja yang telah ditetapkan atau tidak. Dengan demikian kepala lembaga diklat atau stakeholder 
dapat memberikan fasilitas secara tepat dalam mengelola kinerja suatu program diklat.

3. Perencanaan kinerja diklat memberikan arah bagi rencana pengembangan kapasitas dan kompetensi para tenaga kediklatan dengan adanya rencana pengembangan personal di dalam perencanaan kinerja diklat tersebut.

4. Perencanaan kinerja diklat merupakan dasar (pegangan) dalam melakukan review (cross check) kinerja karena review kinerja merupakan ukuran yang digunakan untuk membandingkan antara rencana dengan capaian kinerja diklat.

5. Perencanaan kinerja diklat berfungsi untuk memperkuat komitmen setiap individu tenaga kediklatan dalam rangka mencapai target kinerja diklat tertentu yang di harapkan oleh lembaga diklat. Melalui perencanaan kinerja diklat, setiap individu PNS dituntut untuk menunjukkan komitmennya terhadap targt kinerja yang diharapkan.

6. Perencanaan kinerja juga berfungsi sebagai indicator dalam memeberikan petunjuk bagi perbaikan kinerja diklat kedepan.

Perencanaan kinerja diklat tidak dapat dilakukan sepihak oleh atasan atau oleh bawahan saja. Proses perumusannya dilakukan bersama-sama antara pejabat structural yang mengepalai lembaga diklat dengan pejabat structural yang secara operasional bertanggungjawab terhadap penyelenggaraan suatu program diklat. Pada proses perencanaan kinerja diklat ini diperlukan kesamaan pemahaman antara pejabat structural tersebut terhadap apa yang akan dicapai dari diklat yang akan diselenggarakan.

\section{Perumusan Kesepakatan Kinerja Diklat}

Sebelum merumuskan kesepakatan kinerja diklat, penting untuk memahami hubungan yang jelas antara perencanaan kinerja diklat dan kesepakatan kinerja diklat. Perencanaan kinerja diklat adalah salah satu tahaap didalam manajemen kinerja yang bertujuan untuk merencanakan dan menentukan arah pencapaian kinerja program diklat dan lembaga diklat. Perencanaan kinerja diklat dibuat sebelum kita melakukan review dan penilaian kinerja. Sedangkan kesepakatan kinerja diklat itu sendiri adalah output dari perencanaan kinerja diklat. Kesepakatan kinerja diklat ini adalah sebuah dokumen yang berisikan kesepakatan antara atasan selaku penanggung jawab penyelenggaraan program diklat dngan bawahannya yang secara opersional bertugas menyelenggarakan diklat tersebut. Substansi yang dimuat dalam kesepakatan kinerja diklat tersebut adalah mengenai rencana dan target kinerja yang akan dicapai oleh bawahan untuk suatu jangka waktu tertentu.

Kesepakatan kinerja yang dirancang untuk program diklat dan lembaga diklat memuat 10 (sepuluh) deskripsi yang harus diisi dan disepakati oleh kepala lembaga diklat dana penanggung jawab operasional diklat. Sepuluh hal trsebut adalah:

\section{Data Kepala Lembaga Diklat \& Penanggungjawab Operasional}

Data ini berisikan nama, NIP, pangkat/golongan dan jabaatn dari kepala lembaga diklat dan penanggungjawab operasional. Dua orang inilah yang membuat perncanaan kinerja diklat.

\section{Nama Diklat}

Nama diklat dicantumkan pada kolom yang tersedia. Pada kolom ini dicantumkan nama dan jenis diklat secara lengkap, termasuk angkatan dan tahun berapa diklat tersebut dilaksanakan.

\section{Tujuan Diklat}

Tujuan diklat dicantumkan secara jelas pada kolom yang telah disediakan.

\section{Indicator Kinerja Diklat}

Indicator kinerja diklat adalah uraian yang dapat memberikan petunjuk yang dapat meberikan informasi mengenai tingkat capaian kinerja yang diharapkan. Indicator kinerja diklat ini sangat berguna dalam proses penilaian kinerja diklat. Indicator 
kinerja diklat dirumuskan secara spesifik untuk setiap diklat berdasarkan tujuan dan hasil yang diharapkan dari diklat yang diselenggarakan. Dengan membaca indicator kinerja diklat, seseorang dapat mengetahui tingkat kinerja yang diharapkan dari penyelenggaraan suatu diklat. Indicator kinerja diklat biasanya dirumuskan dalam bentuk persentase atau indicator lain yang dapat dijadikan ukuran dalam melihat capaian kinerja tertentu.

\section{Manfaat Kinerja Diklat}

kinerja diklat menawarkan banyak manfaat bagi efektifitas pengelolaan diklat PNS. Salah satu hal yang membedakan kinerja dengan system penilaian kinerja yang selama ini dipahami oleh banyak PNS adalah review kinerja. Jika di laksanakan secara konsisten, review kinerja diklat memberikan banyak manfaat antara lain:

1. memberikan motivasi dan memperkuat komitmen kedua belah pihak dalam meningkatkan program atau lembaga diklat.

2. Memberikan kejelasan terhadap arah perbaikan kinerja program atau lembaga diklat secara berkelanjutan.

3. Memberikan kontribusi bagi upaya peningkatan kinerja lembaga diklat secara menyeluruh.

4. Menghargai keberhasilan yang dicapai oleh bawahan dan mau belajar dari kekecewaan yang terjadi.

5. Menilai kompetensi dan potensi para penyelenggara program diklat.

6. Menggabungkan gagasan atasan dan bawahan untuk menuju memperbaiki kinerja program dan lembaga diklat.

\section{METODE PENELITIAN}

Penulisan buku ini menggunakan metode deskriptif analitik adalah suatu metode yang berfungsi untuk mendeskripsikan atau memberi gambaran terhadap obyek yang diteliti melalui data atau sampel yang telah terkumpul sebagaimana adanya tanpa melakukan analisis dan membuat kesimpulan yang berlaku untuk umum.

Adapun metode pengumpulan data dilakukan dengan cara wawancara langsung kepada responden untuk mendapatkan data primer. Responden yang hadir yaitu para kepala bidang di perangkat daerah di Provinsi Jambi sesuai urusan pemerintahan yang diwawancara. Data tersebut diolah oleh Kasubbid Pengelolaan Kelembagaan dan Tenaga Pengembangan Kompetensi yang secara langsung menginvertarisir kebutuhan pengembangan kompetensi.

Selain melalui wawancara, untuk mendapatkan data sekunder dilakukan melalui kajian terhadapa literatur-literatur yang tersedia terutama peraturan perundang-undangan yang berkaitan dengan pengembangan kinerja dengan diklat.

\section{KESIMPULAN DAN SARAN Kesimpulan}

Secara sederhana kinerja dapat diartikan sebagai suatu kegiatan atau pekerjaan yang berhasil mencapai tujuan dan memberikan dampak atau manfaat yang kongkrit. Pengertian kinerja tidak hanya mencakup aspek output tapi juga bagaimana cara untuk mencapai output tersebut. Kinerja diklat adalah kinerja yang berhubungan dengan penyelenggaraan suatu program diklat atau kinerja yang berhubungan dengan suatu lembaga diklat. Kinerja diklat menunjukkan tingkat capaian kinerja dari suatu program diklat atau lembaga diklat. Kinerja 
diklat - baik kinerja dari program diklat ataupun kinerja lembaga diklat - memiliki keterkaitan yang sangat erat dengan keberadaan suatu lembaga diklat. Tujuan dari suatu lembaga diklat akan tercapai jika program - program diklat yang di selenggarakan mampu mencapai tingkat kinerja sebagaimana yang diharapkan. Manajemen kinerja untuk program diklat dan lembaga diklat bertujuan untuk meningkatkan kinerja penyelenggaraan program diklat di lembagalembaga diklat melalui tahapan - tahapan pelaksanaan manajemen kinerja. Pengelolaan program-program diklat pada prinsipnya mengikuti siklus manajemen kinerja. Manajemen kinerja diklat di awali dengan perencanaan kinerja diklat atau performance planning for training and development. Perencanaan kinerja diklat adalah tahap awal dari ksungguhan proses implmntasi manajemen kinerja dan merupakan tahap yang sangat menentukan bagi keberhasilan penerapan manajemen kinerja di lembaga-lembaga diklat. Kegagalan dalam melakukan perencanaan kinerja akan membawa konsekuensi bagi tahapan - tahapan selanjutnya. Tanpa perencanaan kinerja yang baik, dapat di pastikan bahwa manajemen kinerja tidak akan menghasilkan kinerja sebagaimana yang di harapkan.

Perencanaan kinerja diklat memiliki banyak fungsi dalam rangka mengawal proses pencapaian kinerja program diklat. Perencanaan diklat ini merupakan fondasi bagi plaksanaan manajemen kinerja di suatu organisasi. Terdapat sejumlah fungsi perencanaan kinerja diklat, antara lain adalah sebagai kerangka dasar bagi implementasi manajemen kinerja bagi program diklat dan lembaga-lembaga diklat, untuk memberikan arah bagi rencana pengembangan kapasitas inkompetensi para tenaga kediklatan untuk memperkuat komitmen setiap individu tenaga kediklatan dalam rangka mencapai target kinerja tertentu yang di harapkan oleh lembaga diklat, dan juga berfungsi sebagai indicator dalam memberikan petunjuk dalam perbaikan kinerja diklat kedepan.

Review kinerja diklat memiliki peran yang sangat penting dalam memanajemen kinerja bagi program diklat dan lembaga diklat karena masa review kinerja dapat berlangsung sepanjang tahun.

\section{Saran}

Untuk mencapai sasaran penelitian program pengembangan sumber daya manusia aparatur pemerintah kabupaten/kota diharapkan :

1. Menjadi pedoman setiap tahun dalam menyusun program pengembangan sumber daya manusia aparatur pemerintah kabupaten/kota yang diselenggarakan setiap awal perencanaan.

2. Diharapkan adanya dukungan pimpinan mengenai ketersediaan anggaran dalam pelaksanaan diklat MOT di BPSDM Provinsi Jambi.

3. Tersedianya stakeholder yang mumpuni dalam menyusun program pengembangan diklat MOT antar pemerintah provinsi dan kabupaten/kota.

\section{DAFTAR RUJUKAN}

Lembaga Administrasi Negara. 2002. Manajemen Proses Kebijakan Publik, Jakarta.

Suparman. 1997. Atwi. Model - model pembelajaran Interaktif. Jakarta. STIA-LAN Press;

Suradji. 2009. Manajemen Diklat. Bahan Kuliah STIA - LAN Jakarta. Jakarta. STIA Press.

Peraturan pemerintah Nomor 11 Tahun 2017 tentang Manajemen Pegawai Negeri sipil.

Undang - undang No. 5 Tahun 2014 tentang aparatur sipil negara.

Lembaga Administrasi Negara. 2016. Teknik Perkonsultasian Diklat. Modul Pelatihan

Kewidyaiswaraan Berjenjang Tingkat Tinggi. Jakarta. 
Lembaga Administrasi Negara. 2016. Evaluasi Sistem Diklat. Modul Pelatihan Kewidyaiswaraan Berjenjang Tingkat Tinggi. Jakarta.

Lembaga Administrasi Negara. 2016. Perancangan Sistem Diklat. Modul Pelatihan Kewidyaiswaraan Berjenjang Tingkat Tinggi. Jakarta.

Lembaga Administrasi Negara. 2016. Inovasi Sistem Diklat. Modul Pelatihan Kewidyaiswaraan Berjenjang Tingkat Tinggi. Jakarta.

Lembaga Administrasi Negara. 2016. Kurikulum Berbasis Lingkungan Strategis. Modul Pelatihan Kewidyaiswaraan Berjenjang Tingkat Tinggi. Jakarta. 